\title{
INDONESIA ZAMRUD KERAGAMAN \\ Upaya Penegelolaan Keragaman
}

\author{
Ahmad Zikri \\ UIN Sultan Syarif Kasim Riau \\ Email: azikrihassan@gmail.com
}

\begin{abstract}
Abstrak
Istilah penting terkait keragaman dalam bahasa Indonesia adalah kebbinnekaan, yang demikian menggambarkan betapa ragamnya bangsa Indonesia. Tulisan ini, ingin mendeskripsikan realitas keragaman tersebut dalam sudut pandang kebudayaan bangsa Indonesia itu sendiri, yang oleb Soekarno disebut sebagai gotong royong. Politik gotong royong yang semula dimaknai oleh penggagasnya, Soekarno, sebagai upaya saling mengisi, membantu, dan berkelindan antar pribadi, justru dipabami sebagai upaya untuk. melakukan kejahatan secara bergotong royong, sebingga memunculkan istila "korupsi berjamaah".
\end{abstract}

Kata kunci; Keragaman, Gotong Royong, Keindonesiaan

\section{Pendahuluan}

Menurut data, hingg tahun 2018 ini, jumlah penduduk Indonesia berjumlah 265 juta (https:// databoks.katadata.co.id). Berdasarkan afiliasi agama, Badan Pusat Statistik tahun 2010 menyebut $87,18 \%$ penduduk Indonesia Muslim, dan $13 \%$ sisanya adalah penganut Kristen, Katolik, Hindu, Budha, Konghucu dan lain-lain (https://databoks.katadata.co.id).

Sementara dari aspek jumlah suku yang tersebar di Indonesi menurut catatan BPS yang bekerjasama dengan ISEAS (Institute of South Asian Studies) menyatakan bahwa terdapat sekitar 633 suku yang diperoleh dari pengelompokan suku dan sub-suku yang ada di Indonesia.
Ribuan pulau yang ada di Negara Kesatuan Republik Indonesia merupakan salah satu ciri bahwa negera ini merupakan negara dengan keragaman suku dan latar belakang kebudayaan yang berbeda-beda. Telah diakui di tingkat internasional bahwa masyarakat Indonesia, baik secara vertikal maupun horizontal, merupakan masyarakat paling majemuk di dunia selain Amerika Serikat dan India (Sudiadi, 2009).

Sejak kemerdekaan Indonesia, data tentang etnisitas sangat terbatas, bahkan sensus penduduk yang oleh Pemerintah Indonesia dari masa kemerdekaan hingga masa pemerintahan Orde Baru belum menyentuh etnisitas (BPS, 2011). Hal itu terkait dengan kebijakan politik 
Pemerintah Indonesia yang berpandangan bahwa perbedaan suku yang dibesarbesarkan merupakan sebuah persoalan yang dapat mengancam persatuan dan kesatuan bangsa.

Pemerintah pun berhati-hati dalam hal ini. Melalui sensus penduduk yang dilaksanakan BPS, pemerintah menghapus pertanyaan mengenai etnisitas dengan alasan pertanyaan tersebut akan mendorong sikap sukuisme dan membahayakan persatuan bangsa.

Survei etnisitas yang pertama kali dilakukan adalah tahun 1930 oleh Pemerintah Hindia Belanda. Banyak diantara para peneliti menggunakan data sensus tersebut sebagai acuan komposisi sukudi Indonesia. Pemerintah berhati-hati dalam menonjolkan perbedaan etnis. Pemerintah masih beranggapan bahwa etnisitas merupakan hambatan untuk tercapainya persatuan dan kesatuan bangsa sehingga pemerintah membentuk opini secara sistematis bahwa etnisitas merupakan konotasi negatif terhadap persatuan dan kesatuan (Tirtosudarmo, 2002).

Hal senada juga diungkapkan oleh Soejatmiko (1983) seperti dikutip Abdullah dalam Jurnal Etnovisi Volume II Nomor 1 Tahun 2006 bahwa pemerintah
Orde Baru menganggap etnisitas dan kesukuan merupakan penghambat pembangunan. Oleh karena itu, keberhasilan pembangunan adalah syarat utama untuk mengatasi perselisihan antarsuku (Abdullah, 2006).

Tulisan ini akan melihat sejauhmana keragaman yang ada itu, menjadi penguat atau pemecah negeri Indonesia ini. Atau sesungguhnya akan menjadi tumbuhkembangnya semagat keragaman atau justru sebaliknya.

\section{Keragaman yang Mengancam}

Indonesia merupakan negara yang dihuni oleh multietnik yang tersebar di berbagai wilayah dan kawasan. Masingmasing etnik itu mempunyai karakter, identitas dan budaya tersendiri pula. Kehadiran keberagaman itu menjadikan bangsa ini mandiri yang bisa dibangun dengan kekuatan-kekuatan keberagaman tersebut. Tetapi kenyataan akhir-akhir ini, keberagaman itu terkoyak oleh berbagai kepentingan dan munculnya sikap-sikap intoleransi dalam realitas kehidupan berbangsa sehingga integritas bangsa yang harmonis terganggu.

Ketergangguan keharmonisan ini, jelas merugikan kedaulatan dan kemajuan bangsa. Goyahnya rasa keharmonisan itu semakin dirasakan di Indonesia. Dari 
berbagai catatan bisa dilihat bahwa beberapa kasus intoleransi dan konflik antaretnis dan agama sempat mencuat.

Pada awal tahun 2017 ini Antropolog Indonesia, telah mengeluarkan petisi bahwa bangsa yang dihuni oleh lebih dari 250 juta jiwa lebih ini tengah mengalami darurat toleransi itu. Petisi ini jelas menunjukkan sebuah prediksi kecemasan tentang kehancuran nasib bangsa Indonesia ke depannya. Jika hal ini dibiarkan, tentu tidak menutup kemungkinan bangsa yang dibangun oleh semangat juang yang tinggi ini akan mengalami the end of history.

Kekhwatiran itu dapat dipahami dengan berbagai data-data kasus yang menggelinding ke ranah sosial kehidupan masyarakat bangsa ini, seperti data kasus intoleransi yang tidak kunjung berhenti sampai awal tahun 2017 ini. Misalnya Puslit Kehidupan Keagamaan Badan Litbang dan Diklat Kementerian Agama RI pernah merekap tentang kasus-kasus intoleransi di Indonesia berdasarkan laporan beberapa lembaga seperti dari SETARA institut menyebut 292 kasus, The Wabid Institute mentatat sebanyak 245 kasus dan CRCS-UGM mencatat 74 kasus.

Pada tahun selanjutnya 2014-2016 data-data kasus intoleransi itu tidak berhenti pula terjadi. Pada tahun 2014 misalnya, The Wabid Institute setidaknya mencatat telah terjadi intolerasi beragama itu sejumlah 245 kasus.2Kemudian pada tahun 2014-2015 sebagaimana dilaporkan oleh Setara Institute Selama tahun 2014 terjadi 134 peristiwa dan 177 tindakan intoleran sedangkan pada tahun 2015 terdapat 197 peristiwa dengan 236 bentuk tindakan pelanggaran kebebasan beragama dan berkeyakinan di Indonesia.

Di berbagai belahan dunia pun kasus-kasus yang demikian juga tengah terjadi. Pertikaian terjadi dari Barat sampai Timur, dari Utara hingga Selatan. Dunia menyaksikan darah mengalir dari Yugoslavia, Cekoslakia, Zaire hingga Rwanda, dari bekas Uni Soviet sampai Sudan, dari Srilangka, India hingga Indonesia. Di Timur Tengah sedang berkecamuk perang saudara, peran antarsuku dan peran antaraliran keagamaan. Kemudian di Asia Tenggara juga tengah terjadi konflik antara Muslim Rohingya dengan umat Budha Myanmar. Tidak kalah penting lagi adalah, kemunculan ISIS yang sangat brutal.

\section{Mengelola Keragaman}

Diskusi mengenai pengelolaan keragaman menjadi topik banyak negara saat ini. Kadang istilah yang digunakan 
multikulturalisme, namun ditempat lain menggunakan istilah pluralisme, bahkan kadang keduanya dipakai bersamaan tanpa ada beban. Padahal, secara teoretis dua istilah itu berasal dari latar belakang sejarah yang berbeda, akan tetapi samasama berbicara mengenai keragaman.

Teori klasik terkait masyarakat plural yang sering dirujuk oleh para sarjana adalah buku J.S Furnivall tentang Indonesia dan M.G. Smith mengenai British West Indies. Furnivall, seorang ahli ekonomi dan staff penjajah pada waktu itu, mendefinisikan masyarakat plural sebagai "comprising two or more elements or social orders, which live side by side, yet without mingling, in one political unit." (Furnivall 1939: 446).

Berdasar observasinya, Furnivall melihat penguasa dan rakyatnya berasal dari dua ras yang berbeda dan tinggal saling berjauhan satu sama yang lain. Karena dididik dalam ilmu ekonomi, analisa Furnivall lebih banyak terfokus pada aspek ekonomi dari jajahan Belanda. Baginya, masyarakat yang plural adalah masyrakat yang tidak ada konsensus.

Masing-masing komunitas memiliki tatanan nilai yang tidak nyambung dengan komunitas yang lain. Untuk menjelaskan poin ini, dia membuat ilustrasi dengan membandingkan antara masyarakat plural dan homogen. Dalam masyarakat homogen, membeli sebuah katedral melibatkan pembiayaan sebagaimana membeli kebutuhan sehari-hari yang memberi manfaat bagi semua warga negara. Akan tetapi, dalam masyarakat plural, pendirian Klenteng bisa jadi "public bad" (keburukan publik) bagi umat Islam; dalam hal yang sama, pendirian masjid memberikan sedikit atau tidak ada manfaat bagi orang Cina.

Jadi, di masyarakat plural, tuntutan sosial seringkali berujung pada pembiayaan publik yang hanya bermanfaat bagi sekelompok masyarakat dan beban pembiayaan bagi yang lain. Karenanya, masyarakat plural gagal membangun tuntutan sosial umum. Namun, karena nilai bagi satu komunitas tidak bisa digunakan sebagai petunjuk untuk mengatur tingkah laku yang lain, ruang pertemuan dari tuntutan semua kelompok ada pada pasar. Apapun perbedaan yang mereka miliki, mereka mempunyai tujuan ekonomi yang sama, yaitu keuntungan.

Dalam kondisi ketiadaan konsensus nasional, kompetisi ekonomi diantara komunitas-komunitas yang berbeda adalah satu-satunya aktivitas bersama yang mungkin terjadi. 
Berdasar observasinya di Indonesia (dulu the Netherlands Indies), paling tidak ada tiga lapisan sosial masyarakat yang terbentuk dari tiga ras yang berbeda. Lapisan yang pertama adalah orang kulit putih yang menjadi pemerintah masyarakat, lapis kedua adalah orangorang (keturunan) Cina yang mendominasi perdagangan dan lapisan yang ketiga adalah masyarakat asli yang kebanyakan bekerja di wilayah pertanian.

Pembagian kerja di masa kolonial ini sebangun dengan pembagian ras. Pendeknya, kontribusi utama Furnivall adalah pada observasinya bahwa masyarakat plural secara kuantitaif berbeda dari yang homogen, identitas ras menunjukkan pekerjaan dan fungsi ekonomi, dan bahwa komunitaskomunitas yang berbeda hanya bisa bertemu di pasar. Dalam hal ini, Furnivall mengabaikan keragaman di dalam (diversity within) satu komunitas (kelompok).

Sementara itu M. G. Smith, sosiolog dengan pengalaman masyarakat plural di Karibia, mengkritik tesis Furnival ini. Dia melihat kesalahan Furnivall dalam menyamakan keragaman budaya dengan stratifikasi kelas, karena keduanya sebenarnya adalah sangat berbeda. Smith mengidentifikasi bagian kultural dari masyarkat melalui praktik-praktik institusinya.

Jadi, ketika kelompok yang berbeda memiliki praktik kelembagaan yang berbeda, maka masyarakat tersebut membutuhkan aturan-aturan yang kuat untuk menjaga keteraturan. (Smith sebagaimana dikutip dalam Robushka dan Shepsle 1972: 16)

Jadi apa yang dimaksud masyarakat plural? Furnifal menjelaskan persoalan ini dengan melihat kehadiran dua atau lebih komunitas yang berbeda, tinggal berdampingan dalam satu unit politik, akan tetapi tidak saling berkait antara yang satu dengan yang lain; pembagian ekonomi berjalan seiring dengan pembagian budaya.

M.G. Smith menajamkan definisi ini dengan memasukkan struktur kelembagaan yang berbeda pada komunitas-komunitas yang berbeda itu. Jadi, apa yang menyebabkan sebuah masyarakat itu plural adalah kelompok budaya yang berbeda dan masing-masing group memiliki tatanan nilai yang tidak saling cocok antara yang satu dengan yang lain. (Rabhuska dan Shepsle 1972: 20)

Karya-karya Furnivall dan Smith ini ditulis oleh orang Eropa dengan 
pengalaman masyarakat homogen di Eropa. Akan tetapi, ada perubahan besar pada tahun 1960-an di Eropa, dimana banyak imigran datang ke Eropa untuk menyukseskan industrialisasi. Para imigran ini, setidaknya, memberi warna baru pada masyarakat homogen Eropa dan membuat beberapa negara harus berpikir bagaimana mengelola komposisi masyarakat yang beragam ini. Salah satu solusinya adalah multikulturalisme.

Multikulturalisme menurut Tariq Modood adalah suatu istilah yang menarik. Ia bisa dipahami berbeda oleh banyak negara tergantung latar belakang sosial politik yang mengiringi kemunculan istilah ini. (Modood 1997).

Di Amerika Serikat, multikulturalisme adalah sebuah istilah yang secara politik digunakan untuk mengakui hak asasi manusia dan kesetaraan warga negara sebagai respon atas meningkatnya klaim atas perbedaan kelompok, seperti etnis Afrika, kelompok etnis minoritas, perempuan, gay dan lain sebagainya. Ia menjadi bagian dari politik identitas untuk mengakui warisan budaya dan bersama yang lain mencari pengakuan publik atas kolektivitas tertentu.

Di Eropa, multikulturalisme adalah respon yang muncul dari imigrasi pendatang dari luar Eropa, dari orang non-kulit putih yang masuk ke negaranegara mayoritas kulit putih. Dalam hal ini, multikulturalisme berbentuk pengakuan atas kelompok-kelompok yang berbeda dalam ruang publik dan memiliki fokus yang lebih sempit. Yakni berfokus pada konsekuensi imigrasi dan perjuangan dari beberapa kelompok marjinal. (Modood 2013:2).

Kebanyakan negara Eropa bisa jadi memiliki pengalaman yang mirip terkait imigrasi, akan tetapi fokus dari kebijakan multikulturalnya bisa bermacam-macam. Di beberapa negara, bisa jadi rasisme dan warisan kolonialisme menjadi sentral; di beberapa yang lain, perhatiannya mungkin tertuju pada bagaiamana merubah kondisi pekerja tamu ini menjadi warga negara yang setara ketika kondisi sebelumnya tidak menawarkan kesempatan untuk menjalankan kuasa demokratis (Modood 2013: 3).

Sejak saat itu, di banyak negara Barat, multikulturalisme menjadi istilah yang populer untuk merespon isu keberagaman. Multikulturalisme memiliki banyak makna (Kallen 1982: 51-62): (1) Pertama, digunakan sebagai respon atas banyaknya keragaman budaya di suatu masyarakat. (2) Kedua, sebagai suatu 
ideologi yang bertujuan untuk melegitimasi masuknya keragaman etnis dalam struktur umum masyarakat. (3) Ketiga, sebagai kebijakan publik yang didesain untuk menciptakan kesatuan nasional dalam etnis yang berbeda-beda.

Sebelum melangkah lebih jauh, baik kiranya jika kita melihat perbedaan antara "multicultural societies" dan "multiculturalist societies". Istilah yang pertama merujuk pada kenyataan bahwa sekarang ini hanya sedikit negara yang dibangun atas komunitas kultural yang homogen. Hampir semua negara terdiri dari berbagai etnis, ras, bahasa, agama, dsb.

Namun, keberagaman ini tidak serta merta menjadikan negara ini sebagai "multiculturalist society", karena istilah ini digunakan untuk merujuk pada "cherishing and encouraging more than one cultural approach, incorporating more than one cultural approach into the majority system of belief and practice, and respecting the cultural demands of all or more than one of the nation-state's communities" (Parekh 2000: 4-5).

Berdasar pada dua perbedaan tersebut, kebanyakan negara-negara Asia adalah multicultural societies, akan tetapi tidak serta merta menjadi multiculturalist society. Negara-negara di Asia sejak semula adalah wilayah yang memiliki keragaman etnis dan budaya yang luar biasa. Mereka memiliki tradisi hidup berdampingan dengan damai sejak dulu. Akan tetapi, penjajahan menjadikan mereka mengabaikan keberagaman masyarakat tersebut dan lebih memberi perhatian pada integrasi sosial untuk mendukung pembangunan dan pembentukan bangsa (Kymlicka \& He, 2005: 2-3).

Pada masa-masa setelah penjajahan, multikulturalisme dan pluralisme secara umum ditekan atas nama persatuan bangsa. Baru beberapa dekade kemudian, keberagaman ini menjadi topik yang tidak bisa dielakkan.

Benar bahwa masyarakat Asia telah memiliki pengalaman hidup damai bersama beberapa budaya, akan tetapi pengalaman mereka tidak memberikan model bagi negosiasi demokratis atas keragaman. Karena itu muncullah keinginan dari berbagai negara di Asia untuk mengeksplorasi pengalaman Barat mengenai demokrasi dan pengelolaan keragaman. Isu keragaman etnobudaya, kewargaan, hak asasi manusia dan hubungan antara kelompok minoritas dan negara juga cukup banyak di negara-negara Asia. 


\section{Memperkuat Gotong Royong}

Tidak diragukan lagi bahwa disepanjang sejarah agama dapat memberi sumbangsih positif bagi masyarakat dengan memupuk persaudaraan dan semangat kerjasama antar anggota masyarakat. Namun sisi yang lain, agama juga dapat sebagai pemicu konflik antar masyarakat beragama. Ini adalah sisi negatif dari agama dalam mempengaruhi masyarakat dan hal ini telah terjadi di beberapa tempat di Indonesia. Dengan keanekaragaman agama yang ada di Indonesia membuat masyarakat Indonesia memiliki pemahaman yang berbeda-beda sesuai dengan yang diajarkan oleh agamanya masing-masing. Perbedaan ini timbul karena adanya doktrin-doktrin dari agama-agama, suku, ras, perbedaan kebudayaan, dan dari kelompok minoritas dan mayoritas.

Pertama. Semua pihak umat beragama yang sedang terlibat dalam bentrokan masingmasing menyadari bahwa justru perbedaan doktrin itulah yang menjadi penyebab dari benturan itu. Entah sadar atau tidak, setiap pihak mempunyai gambaran tentang ajaran agamanya, membandingkan dengan ajaran agama lawan, memberikan penilaian atas agama sendiri dan agama lawannya. Dalam skala penilaian yang dibuat (subyektif) nilai tertinggi selalu diberikan kepada agamanya sendiri dan agama sendiri selalu dijadikan kelompok patokan, sedangkan lawan dinilai menurut patokan itu. Agama Islam dan Kristen di Indonesia, merupakan agama samawi (revealed religion), yang meyakini terbentuk dari wahyu Ilahi Karena itu memiliki rasa superior, sebagai agama yang berasal dari Tuhan.

Kedua, Agama sebagai bagian dari budaya bangsa manusia. Kenyataan membuktikan perbedaan budaya berbagai bangsa di dunia tidak sama. Tempattempat terjadinya konflik antar kelompok masyarakat agama Islam - Kristen, perbedaan antara dua kelompok yang konflik. Kelompok masyarakat setempat memiliki budaya yang sederhana atau tradisional: sedangkan kaum pendatang memiliki budaya yang lebih maju atau modern. Karena itu bentuk rumah gereja lebih berwajah budaya Barat yang mewah. Perbedaan budaya dalam kelompok masyarakat yang berbeda agama di suatu tempat atau daerah ternyata sebagai faktor pendorong yang ikut mempengaruhi terciptanya konflik antar kelompok agama di Indonesia.

Ketiga. Fenomena konflik sosial mempunyai aneka penyebab. Tetapi dalam 
masyarakat agama pluralitas penyebab terdekat adalah masalah mayoritas dan minoritas golongan agama. Masalah mayoritas dan minoritas ini timbul dikarenakan kekuatan dan kekuasaan yang lebih besar kelompok moyoritas dari pada kelompok minoritas sehingga timbul konflik yang tak terelakan. Dikarenakan saling menunjukan pembenaran dari masing-masing pemahaman dari doktrindoktirn yang di berikan dalam kelompok mayoritas dan minoritas. Mengakibatkan timbulnya konflik dari kelompok mayoritas dengan kelompok minoritas.

Oleh karena itu, perlu kesadaran baru dalam merawat zamrud keragaman negeri ini, sehingga tidak mewarisi perpecahan dan permusuhan.

Indonesia, menurut Soekarno, didirikan bukan hanya untuk orang Jawa atau untuk umat tertentu saja. Soekarno hendak memperkenalkan pemahaman bahwa Indonesia didirikan untuk menjamin kepentingan semua warga Indonesia ketika mengatakan bahwa Negara Indonesia adalah Negara gotong royong.

Soekarno mengatakan bahwa prinsip gotong royong ini khas Indonesia. Soekarno dengan demikian konsisten dengan uraian di awal pidatonya yang mengatakan bahwa dasar negara ini haruslah berasal dari jiwa masyarakat Indonesia yang terdalam dan tidak dipunyai bangsa lain:

Gotong royong adalah faham yang dinamis, lebih dinamis dari kekeluargaan, saudara-saudara! Kekeluargaan adalah satu faham yang statis, tetapi gotong royong menggambarkan satu usaha, satu amal, satu pekerjaan, yang dinamakan anggota yang terhormat Soekardjo: satu karyo, satu gawe. Marilah kita menyelesaikan karyo, gawe, pekerjaan amal ini, bersama-sama! Gotong royong adalah pembanting tulang bersama, pemerasan keringat bersama, perjuangan bantubinantu bersama, amal semua buat kepentingan semua, keringat semua buat kebahagiaan semua, holopis kuntul baris buat kepentingan bersama! Itulah gotong royong! (Sekretariat Negara Republik Indonesia, 1995: 82)"

Soekarno menyadari bahwa prinsip gotong royong ini diasalkan dari paham Jawa, di mana semua bekerja sama untuk menyelesaikan "gawve" dan "karyo" bersama. Soekarno mengutip perkataan Soekardjo untuk menjelaskan makna gotong royong. Siapakah Soekardjo?

Raden Soekardjo Wirjopranoto adalah pemimpin surat kabar Asia Raya dan anggota Panitia Adat dan Tatanegara. Soekardjo menjadi salah satu peserta dalam sidang ini dan ahli di bidang 
redaksional, sehingga pantas jika Soekarno mengutip perkataannya. Definisi gotong royong yang dikemukakan Soekardjo pun berupa terminologi Jawa; yakni "karyo" dan "gawe."

Soekarno di titik ini hendak meyakinkan para peserta sidang akan kekukuhannya untuk menggali dasar negara dari bumi Indonesia sendiri. Gotong royong adalah khas Indonesia. Darmawan (2005:20) di titik ini berpendapat bahwa Soekarno ingin supaya para bapak pendiri bangsa diikat oleh pemahaman bersama bahwa negara Indonesia diasalkan dari prinsip khas Indonesia sendiri dan didirikan demi kepentingan semua warga, sehingga semua bertanggung jawab atas kelangsungan bangsa.

Khrisna (2005:8- 9) mengatakan bahwa gotong royong bukanlah sikap kekurangberanian, kurang percaya diri, atau sikap tidak mandiri. Gotong royong juga tidak cuma berarti membantu tetangga memperbaiki atap rumahnya. Interpretasiinterpretasi seperti ini justru mengkhianati semangat gotong royong itu sendiri Khrisna (2005:8-9). Khrisna (2005:8-9) mengatakan bahwa gotong royong berarti bahu-membahu. Gotong royong berarti saling bergandengan tangan. Gotong royong adalah sebuah "kesadaran" bahwa semua adalah putra-putri ibu pertiwi yang mempunyai hak dan kewajiban yang sama, walaupun pelaksanaannya dan penerjemahannya dalam hidup sehari-hari bisa berbeda.

\section{Penutup}

Memperjuangkan Indonesia untuk semua juga menjadi hal yang amat relevan dewasa ini. Pemahaman bahwa Indonesia untuk semua akan mengikis habis kecenderungan baik itu separatis maupun kehendak untuk memaksakan ideologi tertentu. Perjuangan untuk mewujudkan hal ini hanya mungkin dalam bingkai semangat gotong royong. Negara ada bukan demi kekuasaan. Soekarno bahkan lebih lanjut menunjukkan bahwa negara harus dikelola dalam semangat kegotong-royongan.

Dalam bahasa Hatta, negara semacam inilah yang disebut negara pengurus. Negara kekuasaan (untuk mengatakan sebagai lawan negara pengurus) adalah negara yang dikelola dengan semangat Macchiavellian di mana seorang penguasa dituntut untuk mempertahankan kekuasaannya dengan berbagai cara. Sebaliknya, negara pengurus mengedepankan pengertian bahwa sang pemegang kekuasaan adalah pengurus, pengelola, pengemban, atau dalam bahasa 
UUD'45 disebut mandataris (sang pengemban mandat).

\section{DAFTAR PUSTAKA}

BPS. 2011. Kewarganegaraan, Suku Bangsa, Agama, dan Bahasa Sehari-Hari Penduduk Indonesia: Hasil Analisis Sensus Penduduk 2010. Jakarta: BPS

BPS. 2015. Bunga Rampai Analisis Determinan Hasil SP 2010. Jakarta: BPS

Aqsha, Darul, Dick van der Meij, Johan Hendrik Meuleman. 1995. Islam in Indonesia: A survey of Events and Developments from 1988 to March 1993. Jakarta: Indonesia Netherlands Islamic Services (INIS)

Azra, Azyumardi. 2004. "Managing Pluralism in Southeast Asia: Indonesia Experience", Peace Research, Vol. 36, No. 1 (May 2004): 43-56

Chang-Yau Hoon. 2006. "Assimilation, Multiculturalism, Hybridity: The dilemmas of the Ethnic Chinese in Post-Suharto Indonesia", Asian Ethnicity, 7(2)

Commack, Mark, Lawrence A. Young, Tim Heaton. 1996. "Legislating Social Change in an Islamic Society - Indonesia'a Marriage Law, The American Journal of Comparative Law, Vol. 44, No. 1 (Winter, 1996)

Connor, Walker. 1999. "National SelfDetermination and Tomorrow's Political Map", in Alan Cairns et al. (eds), Citizenship, Diversity and Pluralism: Canadian and Comparative Perspective. Montreal: McGill-Queen's University Press: 163-176 
Cribb, R. \& C. Brown. 1997. Modern Indonesia: A History Since 1945. London: Longman

Effendy, Bachtiar. 2011. Islam dan Negara: Transformasi Gagasan dan Praktik Politik Islam di Indonesia, edisi digital. Jakarta: Democracy Project.

Federspiel, Howard. 1998. "Islamic Values, Law and Expectations in Contemporary Indonesia", Islamic Law and Society, Vol. 5 (1): 90-117

Feener, R. Michael. 2007. Muslim Legal Thoughts in Modern Indonesia. Cambridge, New York, Melbourne, Madrid, Cape TOwn, Singapore, Sao Paulo: Cambridge University Press,

Furnivall, J.S. 1939. Netherlands India. Cambridge, Massachusset: Harvard University Press

Gaffar, Affan. 1993. "Politik Akomodasi: Islam dan Negara di Indonesia", dalam M. Imam Aziz, M. Jadul Maula, Ellyasa KH Darwis (eds), Agama, Demokrasi \&o Keadilan. Jakarta: Gramedia Pustaka Utama

Harrison, Lawrence E. 2008. "The End of Multiculturalism", The National Interest No. 93 (Jan/Feb. 2008): 8896

Hefner, Robert W. 2011. "Indonesia: Shari'a Politics and Democratic Transition" in Robert W Hefner (ed), Shari'a Politics: Islamic Law and Jurnal Pemikiran Sosiologi Volume 4 No. 2, 2017 Keragaman di Indonesia dan Politik Pengakuan (Suatu

Tinjauan Mustaghfiroh

Society in the Modern World. Indiana: India University Press
Heryanto, Ariel. 1999. "Rape, Race and Reporting", in Budiman, Arief, B Hatley and D. Kingsbury (Eds), Reformasi: Crisis and Change in Indonesia. Clayton: Monash Asia Institute: 299-334.

Hisyam, Muhammad. 1996. "The Dynamics of Religion and State Relations in Indonesia: The Case of the Islamic Court," Paper presented at the First International Conference on Islam and the 21st Century. Leiden, June 1996. Unpublished.

Indiyanto, Agus. 2013. Agama di Indonesia dalam Angka: Dinamika Demografis Berdasarkan Sensus Penduduk 2000 dan 2010. Yogyakarta: CRCS

Kallen, E. 1982. Multiculturalism: Ideology, Policy and Reality". Journal of Canadian Studies 17 (1)

Llyoyd, G.J. ]d G.J. Lyoyd (Eds), Perspective on the Chinese Indonesians. Adelaide: Crawford House:1-19 Lovett,Frank. 2010. "Cultural Accommodation and Domination", Political Theory 2010; 38 (2); 243-267.

Lubis, Nur Ahmad Fadhil. 1995. "Institutionalization and the Unification of Islamic Court under

the New Orser," Studia Islamika Vol 2 (1): $1-51$

Migdal, Joel S. 1994. "The State in Society: An Approach to Struggle for Domination", in Migdal, Joel S. et.al. (eds), State Power and Social Forces: Domination and Transformation in the Third World. Cambridge, New York, Melbourne: Cambridge University Press.

Modood, Tariq, 1997. "Introduction", in Tariq Modood and Pnina Werbner (eds), The Politics of 
Multiculturalism in the New Europe: Racism, Identity, and Community. London: Palgrave Macmillan

Modood, Tariq. 2013. Multiculturalism: A Civic Idea (Second Edition). Cambridge: Polity Press

Mujiburrahman. 2006. Feeling Thretened: MuslimChristian Relations in Indonesia's New Order. Leiden: ISIM, Amsterdam University Press

Nandy, Ashis. 1992. "Federalism, the Ideology and the State and Cultural Pluralism", in N. Mukarji and B. Arora (eds), Federalism inIndia: Origins and Development. Delhi: Vikas Publishing: 27-40

Noer, Deliar. 1978. The Administration of Islam in Indonesia. Ithaca: Cornell Modern Indonesia Project

Noor, Firman. 2012. Institutionalising Islamic Political Parties in Indonesia: A Study of Internal Fragmentation and Cohesion in the Post-Soeharto Era (1998-2008). University of Exeter: PhD Thesis.

Otto, Jan Michiel. 2010."Sharia and National Law in Indonesia", in Jan Michiel Otto, Sharia Incorporated: A Comparative verview of the Legal Systems of Twelve Muslim Countries in Past and Present. Leiden: Leiden University Press

Parekh, Bikhu. 1998. A Commitment to Cultural Pluralism. Paper presentented in Intergovermental Conference on Cultural Policiesn for Development, Stickholm, Sweden, 30 March - 2 APril 1998. 